\title{
ADDITIONAL SPECIMENS OF HYOTISSA MCGINTYI (MOLLUSCA: BIVALVIA: GRYPHAEIDAE) FROM NORTH CAROLINA
}

\author{
DOUGLAS A. WOLFE
}

109 Shore Drive, Beaufort, NC 28516

ARTHUR E. BOGAN

NC State Museum of Natural Sciences, MCS 1626 Research Laboratory Raleigh, NC 27699

Key Words: Hyotissa; North Carolina; oyster; Gryphaeidae.

On 10 January 2013, just as the note by Wolfe et al. (2013) was in press, Jamie M. Smith and Heather B. Fredricks at the North Carolina Museum of Natural Sciences were in the final stages of integrating the last lots of mollusks transferred from the UNC Institute of Marine Sciences in Morehead City [UNC-IMS] to North Carolina Museum of Natural Sciences, Raleigh during summer 2012. Among this material they discovered a lot of Hyotissa megintyi, consisting of one preserved specimen and one single (unattached) dry valve, collected "17 March 1969 from [Atlantic Ocean], ESE of Cape Fear, NC. [61.73 air miles $(99.3 \mathrm{~km}) \mathrm{SE}$ center] Menzies Reef Area, depth 330-200 (100-61 m), small biological trawl, M/V Eastward Cruise station 11552 " by Hugh J. Porter and Charles Jenner, with the UNC-IMS catalog number 4426. Station coordinates were $33^{\circ} 25.4^{\prime} \mathrm{N}$ latitude; $77^{\circ} 01^{\prime} \mathrm{W}$ longitude. The preliminary identification with the lot was simply "Ostrea." Hugh Porter sent the preserved specimen to
Harold W. Harry for identification in November of 1981, and the specimen was diagnosed as Hyotissa thomasi McLean, 1941 (renamed in 1985 by Harry as Parahyotissa mcgintyi - now Hyotissa mcgintyi). This specimen undoubtedly was the basis for Harry's (1985) otherwise undocumented claim that the range of the species extended northward to North Carolina.

This lot, now catalogued as NCSM 14522, positively documents the presence of this species on the livebottom reefs occurring off the coast of southeastern North Carolina.

\section{LITERATURE CITED}

HARRY, H. W. 1985. Synopsis of the supraspecific classification of living oysters (Bivalvia: Gryphaeidae and Ostreidae). The Veliger 28:121-158.

WOLFE, D. A., A. E. FOGLEMAN, and A. E. BOGAN. 2013. Hyotissa mcgintyi found in North Carolina [Mollusca, Bivalvia, Gryphaeidae]. J. N.C. Acad. Sci. 129(1):34-36. 